\title{
Spectro-magnetic and Antimicrobial Studies on Some 3d metal Complexes with Ethylenedianil of ortho-hydroxyphenylglyoxal
}

\author{
Ali Mohammed Yimer ${ }^{1, *}$, T. Baraki ${ }^{2}$, R. K. Upadhyay², Masood Akhtar ${ }^{1}$ \\ ${ }^{1}$ Department of Applied Chemistry, College of Natural and Computational Sciences, Arba Minch University (Ethiopia) \\ ${ }^{2}$ Department of Chemistry, College of Natural and Computational Sciences, Hramaya University (Ethiopia)
}

\section{Email address:}

ali.mohammed@amu.edu.et (A. M. Yimer)

\section{To cite this article:}

Ali Mohammed Yimer, T. Baraki, R. K. Upadhyay, Masood Akhtar. Spectro-Magnetic and Antimicrobial Studies on some 3d Metal Complexes with Ethylenedianil of Ortho-Hydroxyphenylglyoxal. American Journal of Applied Chemistry. Vol. 2, No. 1, 2014, pp. 15-18. doi: 10.11648/j.ajac.20140201.14

\begin{abstract}
The} \mathrm{Cr}(\mathrm{III}), \mathrm{Fe}(\mathrm{III}), \mathrm{Co}(\mathrm{II}), \mathrm{Ni}(\mathrm{II}), \mathrm{Cu}(\mathrm{II})$ and $\mathrm{Zn}(\mathrm{II})$ complexes with a novel tetradentate ligand obtained by condensation of ethylenediamine with ortho-hydroxyphenylglyoxal have been synthesized and characterized by elemental analysis, molar conductance and magnetic susceptibility measurements, IR, UV-Visible and atomic absorption studies. The $\mathrm{Cr}(\mathrm{III}), \mathrm{Fe}(\mathrm{III})$ and $\mathrm{Co}(\mathrm{II})$ complexes possess six coordinate octahedral geometry whereas $\mathrm{Ni}(\mathrm{II}), \mathrm{Cu}(\mathrm{II})$ and $\mathrm{Zn}$ (II) complexes are square planar and tetrahedral respectively. Bactericidal and fungicidal activities of the compounds were evaluated in vitro by disc diffusion method. The perusal of antimicrobial activities of the compounds reveals that the complexes possess greater bactericidal and fungicidal activities against all the microbes in comparison to ligand which is due to their higher lipophilicity.
\end{abstract}

Keywords: Bactericidal and Fungicidal Activities, Ortho-Hydroxyphenylglyoxal, Thin-Layer Chromatography, Structural Geometry, Lipophilicity, Tetradentate Ligand

\section{Introduction}

Polydentate ligands in the field of coordination chemistry and their metal complexes (chelates) are of great interest since many years. It is well known that $\mathrm{N}, \mathrm{S}$ and $\mathrm{O}$ atoms play a key role in the coordination of metals at the active sites of numerous metallobiomolecules[1]. Chelating ligands containing $\mathrm{O}, \mathrm{N}$ and $\mathrm{S}$ donor atoms show broad spectrum of biological activities and are of special interest because of the variety of ways in which they are bonded to metal ions [1,2]. Most complexes of Schiff's bases act as perfect chelating agents and, are highly biologically active [3]

Ketonil Schiff's bases with ON donor binding sites have attracted considerable attention because of their preparative accessibility, potential biological properties [ 2,4] applications in industries as dyes [4] and versatile coordination properties leading to formation of stable complexes with transition metal ions in unusual coordination numbers and isomeric structures [5-8]. The multifarious biological including antipathogenic behavior of these metal-Schiff's base complexes is of paramount importance for designing metal-based drugs. In view of mentioned distinguished features of these compounds we report here the synthesis, magnetic, spectral and antimicrobial studies of $\mathrm{Cr}$ (III), $\mathrm{Fe}(\mathrm{III}), \mathrm{Co}(\mathrm{II}), \mathrm{Ni}(\mathrm{II})$, $\mathrm{Cu}(\mathrm{II})$, and $\mathrm{Zn}(\mathrm{II})$ complexes with ethylenedianil of orthohydroxyphenylglyoxal.

\section{Experimental}

The ligand ethylenedianil of orthohydroxyphenylglyoxal (L) was synthesized by the condensation of ethylenediamine and orthohydroxyphenylglyoxal [4]. The reaction mixture containing ethylenediamine $(0.25 \mathrm{~mol})$ and orthohydroxyphenylglyoxal $(0.5 \mathrm{~mol})$ in ether was stirred at room temperature $\left(\sim 20{ }^{0} \mathrm{C}\right)$. The yellow brawn precipitate obtained was crystallized from acetone and product was finally washed with ether and dried in air.

The complexes of Fe(III), $\mathrm{Co}(\mathrm{II}), \mathrm{Ni}$ (II) and $\mathrm{Zn}$ (II) were synthesized by refluxing their reaction mixtures containing metal chloride $(0.01 \mathrm{~mol})$ and ligand $(0.01 \mathrm{~mol})$ in 
acetone/methanol for $1 \mathrm{~h}$ at $\sim 75{ }^{0} \mathrm{C}$. Concentrated reaction mixtures on cooling in ice bath yielded solid powders which were washed with cold water and acetone/methanol successively and dried in air. The $\mathrm{Cr}$ (III) and monoligand $\mathrm{Cu}$ (II) complexes precipitated from their reaction mixtures immediately were filtered out, washed with acetone and dried in air. To the filtrate of monoligand $\mathrm{Cu}$ (II) complex on further adding the ligand $\mathrm{Cu}$ (II)-bis-ligand complex precipitated was filtered out, washed with acetone and dried in air.

The purity of the compounds was tested by TLC on silica gel layers using chloroform, acetone and butanol solvents.

For the bacterial and fungicidal activities, compounds were screened in vitro by Disc Difffusion method [8] against animal pathogens, viz. Escherichia coli, Staphylococcus aureus and xanthomonas holcicola (bactria) and Aspergillus niger, Colletotrichum gloeosporioides and Fusarium oxysporm (fungi).

Melting pints were determined in open glass capillaries with Stuart SMP-10 melting point apparatus and are uncorrected. Microanalyses were performed on a Vario ELIII analyzer. IR spectra were recorded on Shimadzu Prestize-21 FT-IR spectrophotometer in 4000-200 $\mathrm{cm}^{-1}$ region in $\mathrm{KBr}$ medium. The electronic spectra were recorded on SP65 UV-Vis. spectrophotometer in methanol solvent. Magnetic susceptibility was measured at room temperature $\left(295{ }^{\circ} \mathrm{C}\right)$ on MSB-Auto (Sherwood Scientific Ltd) balance. The molar conductance of complexes was measured in methanol at room temperature on Jenway digital conductivity bridge. Metal contents of the complexes were determined by atomic absorption spectroscopy using BUCK Scientific spectrophotometer.

\section{Results and Discussion}

All the metal complexes are stable in air. Microanalytical data (Table 1) are consistent with the molecular formulae of the compounds. The molar conductance values account for
[10] non-electrolytic nature of $\mathrm{Cr}$ (III), $\mathrm{Fe}(\mathrm{III}), \mathrm{Co}$ (II) and $\mathrm{Ni}(\mathrm{II})$ complexes, and 1:2 and 1:1 electrolytic nature of the two $\mathrm{Cu}(\mathrm{II})$ and $\mathrm{Zn}(\mathrm{II})$ complexes respectively.

In order to identify the binding modes of the ligand in the complexes, IR spectrum of the free ligand was compared with that of complexes. The free ligand displayed $\nu \mathrm{OH}$ and $v \mathrm{C}-\mathrm{O}$ bands at $3458 \mathrm{~cm}^{-1}$ and $1066 \& 1129 \mathrm{~cm}^{-1}$ of phenolic/enolic groups. In the spectra of the complexes the absence of $v \mathrm{OH}$ band, lowering in frequency of $\mathrm{vC}-\mathrm{O}$ bands (ca. $1045 \&$ ca. $1103 \mathrm{~cm}^{-1}$ ) and appearance of a new band in $488-561 \mathrm{~cm}^{-1}$ attributed to $v \mathrm{M}-\mathrm{O}$ reveal coordination of deprotonated phenolic/enolic group of the ligand; an additional band appeared in $453-473 \mathrm{~cm}^{-1}$ region in the spectra of $\mathrm{Cu}$ (II) and $\mathrm{Zn}$ (II) complexes could be attributed to $v \mathrm{M}-\mathrm{O}-\mathrm{M}$ vibrations. The azomethine group stretching vibration, displayed in ligand spectrum at 1613 $\mathrm{cm}^{-1}$, appeared at low value $\left(1457-1538 \mathrm{~cm}^{-1}\right)$ in complexes indicates coordination of azomethane nitrogen with metals. The appearance of new band in $465-489 \mathrm{~cm}^{-1}$ range in complex spectra attributed to $v \mathrm{M}-\mathrm{N}$ supported the presence of azomethane group in the coordination zone of the metals. The shifting of $v \mathrm{C}=\mathrm{O}$ band of ligand $\left(1646 \mathrm{~cm}^{-1}\right)$ on complexation in $1602.1642 \mathrm{~cm}^{-1}$ range is a strong evidence in support of the view regarding coordination of deprotonated enolic group of quinonoid structure of the ligand [2].

A band at $375 \mathrm{~cm}^{-1}, 303 \mathrm{~cm}^{-1}$ and $247 \mathrm{~cm}^{-1}$ in $\mathrm{Fe}(\mathrm{III})$, $\mathrm{Zn}$ (II) and mono-ligand trinuclear $\mathrm{Cu}(\mathrm{II})$ are assigned to $v \mathrm{M}-\mathrm{Cl}$ and $v \mathrm{Cu}-\mathrm{Cl}-\mathrm{Cu}$ vibrations of monodentate and bidentate chloride respectively. Two infrared active $v \mathrm{Cr}-\mathrm{Cl}$ bands at $248 \mathrm{~cm}^{-1}$ and $377 \mathrm{~cm}^{-1}$ of monodentate chloride in $\mathrm{Cr}$ (III) complex indicates its $\mathrm{C}_{2 \mathrm{v}}$ (trans symmetry) [10,11].

Lattice water exhibited symmetric and antisymmetric stretching and bending vibrations in $3209-3493 \mathrm{~cm}^{-1}$ and $1601-1630 \mathrm{~cm}^{-1}$ regions respectively, whereas coordinated water displayed wagging $\left(\rho_{\mathrm{w}}\right)$, twisting $\left(\rho_{\mathrm{t}}\right)$, rochking $\left(\rho_{\mathrm{r}}\right)$ vibrations and $v \mathrm{M}-O H_{2}$ peak in $832-1044 \mathrm{~cm}^{-1}$ and 252-399 $\mathrm{cm}^{-1}$ regions respectively of complex spectra.

Table 1. Analytical data, magnetic moment and physical properties of compounds

\begin{tabular}{|c|c|c|c|c|c|c|c|c|c|c|}
\hline \multirow[t]{2}{*}{ S.No. } & \multirow[t]{2}{*}{ Compounds } & \multirow[t]{2}{*}{ Color } & \multirow{2}{*}{$\begin{array}{l}\text { Yield } \\
\text { (\%) }\end{array}$} & \multirow{2}{*}{$\begin{array}{l}\text { M.P } \\
\left({ }^{0} \mathrm{C}\right)\end{array}$} & \multirow{2}{*}{$\begin{array}{l}\text { Molar Cond. } \\
\left(\Omega^{-1} \mathrm{~cm}^{2} \mathrm{~mol}^{-1}\right)\end{array}$} & \multirow{2}{*}{$\begin{array}{l}\mu_{\text {eff }} \\
\text { (B.M.) }\end{array}$} & \multicolumn{4}{|c|}{$\begin{array}{l}\text { Elemental analysis (\%) } \\
\text { Calculated. (Found) }\end{array}$} \\
\hline & & & & & & & C & H & $\mathbf{N}$ & $\mathbf{M}$ \\
\hline 1 & $\mathrm{C}_{18} \mathrm{H}_{16} \mathrm{~N}_{2} \mathrm{O}_{4}$ & Yellow & 41 & $152 \pm 2$ & - & - & $\begin{array}{l}66.67 \\
(67.01)\end{array}$ & $\begin{array}{l}4.94 \\
(4.62)\end{array}$ & $\begin{array}{l}8.64 \\
(8.43)\end{array}$ & - \\
\hline 2 & {$\left[\mathrm{Cr}_{2} \mathrm{~L}\left(\mathrm{H}_{2} \mathrm{O}\right)_{2} \mathrm{Cl}_{4}\right] \cdot 6 \mathrm{H}_{2} \mathrm{O}$} & Gray & 63 & $>300$ & 7.8 & 3.83 & $\begin{array}{l}30.33 \\
(30.77)\end{array}$ & $\begin{array}{l}4.21 \\
(4.45)\end{array}$ & $\begin{array}{l}3.93 \\
(3.76)\end{array}$ & $\begin{array}{l}14.57 \\
(13.67)\end{array}$ \\
\hline 3 & {$\left[\mathrm{FeL}\left(\mathrm{H}_{2} \mathrm{O}\right) \mathrm{Cl}\right] \cdot 6 \mathrm{H}_{2} \mathrm{O}$} & Black & 65 & $195 \pm 2$ & 5.6 & 3.64 & $\begin{array}{l}40.04 \\
(40.5)\end{array}$ & $\begin{array}{l}5.19 \\
(4.98)\end{array}$ & $\begin{array}{l}5.19 \\
(5.28)\end{array}$ & $\begin{array}{l}10.38 \\
(9.83)\end{array}$ \\
\hline 4 & {$\left[\mathrm{CoL}\left(\mathrm{H}_{2} \mathrm{O}\right)_{2}\right] \cdot 4 \mathrm{H}_{2} \mathrm{O}$} & Gray & 83 & $185 \pm 2$ & 11.0 & 3.73 & $\begin{array}{l}44.17 \\
(44.58)\end{array}$ & $\begin{array}{l}5.32 \\
(5.80)\end{array}$ & $\begin{array}{l}5.72 \\
(5.54)\end{array}$ & $\begin{array}{l}12.07 \\
(11.48)\end{array}$ \\
\hline 5 & {$[\mathrm{NiL}] . \mathrm{H}_{2} \mathrm{O}$} & Brown yellow & 64 & $245 \pm 2$ & 39.7 & 1.25 & $\begin{array}{l}54.18 \\
(54.42)\end{array}$ & $\begin{array}{l}4.01 \\
(4.86)\end{array}$ & $\begin{array}{l}7.59 \\
(8.06)\end{array}$ & $\begin{array}{l}14.72 \\
(15.56)\end{array}$ \\
\hline 6 & {$\left[\mathrm{Cu}_{3} \mathrm{~L}_{2}\right]^{+2} \cdot 2 \mathrm{Cl}^{-} \cdot 4 \mathrm{H}_{2} \mathrm{O}$} & Black green & 58 & $278 \pm 2$ & 159.7 & 1.23 & $\begin{array}{l}44.20 \\
(43.55)\end{array}$ & $\begin{array}{l}3.30 \\
(3.44)\end{array}$ & $\begin{array}{l}7.59 \\
(8.02)\end{array}$ & $\begin{array}{l}19.50 \\
(20.27)\end{array}$ \\
\hline 7 & {$\left[\mathrm{Cu}_{3} \mathrm{LCl}_{2}\left(\mathrm{H}_{2} \mathrm{O}\right)_{2}\right] \cdot 2 \mathrm{Cl}^{-}$} & Green brown & 42 & $283 \pm 2$ & 154.2 & 1.19 & $\begin{array}{l}31.28 \\
(32.13)\end{array}$ & $\begin{array}{l}2.32 \\
(2.49)\end{array}$ & $\begin{array}{l}4.05 \\
(4.42)\end{array}$ & $\begin{array}{l}28.99 \\
(30.10)\end{array}$ \\
\hline 8 & $\begin{array}{l}{\left[\mathrm{Zn}_{2} \mathrm{LCl}\left(\mathrm{H}_{2} \mathrm{O}\right)\right]^{+} \cdot \mathrm{Cl}^{-}} \\
.4 \mathrm{H}_{2} \mathrm{O}\end{array}$ & Light yellow & 82 & $>300$ & 86.5 & Diamag. & $\begin{array}{l}35.19 \\
(34.83)\end{array}$ & $\begin{array}{l}3.58 \\
(3.89)\end{array}$ & $\begin{array}{l}4.59 \\
(5.06)\end{array}$ & $\begin{array}{l}14.25 \\
(14.93)\end{array}$ \\
\hline
\end{tabular}

$\mathrm{L}=\mathrm{C}_{18} \mathrm{H}_{14} \mathrm{~N}_{2} \mathrm{O}_{4}$ 
Magnetic moment of $\mathrm{Cr}(\mathrm{III})$ complex $(3.83 \mathrm{BM})$ is typical of spin-free $\mathrm{d}^{3}$ octahedral geometry. Among the four peaks displayed in the absorption spectrum at $14286 \mathrm{~cm}^{-1}$, $24390 \mathrm{~cm}^{-1}, 30303 \mathrm{~cm}^{-1}$ and $34482 \mathrm{~cm}^{-1}$ first three band are characteristic of ${ }^{4} \mathrm{~A}_{2 \mathrm{~g}} \rightarrow{ }^{4} \mathrm{~T}_{2 \mathrm{~g}}(\mathrm{~F}),{ }^{4} \mathrm{~A}_{2 \mathrm{~g}} \rightarrow{ }^{4} \mathrm{~T}_{1 \mathrm{~g}}(\mathrm{~F}),{ }^{4} \mathrm{~A}_{2 \mathrm{~g}} \rightarrow$ ${ }^{4} \mathrm{~T}_{1 \mathrm{~g}}(\mathrm{P}) \mathrm{d}$-d transitions respectively $[13,14]$ and fourth band attributed to ligand to metal charge transfer [13].

Although in absence of antiferromagnetic interactions low magnetic moment, $3.64 \mathrm{BM}$, of $\mathrm{Fe}$ (III) complex indicates high spin $(S=5 / 2)$ to low spin $(S=1 / 2)$ crossover phenomenon [10] but electronic spectral bands splitting pattern is characteristic of high-spin octahedral geometry. Absorption bands at $20833 \mathrm{~cm}^{-1}, 24390 \mathrm{~cm}^{-1}, 27027 \mathrm{~cm}^{-1}$, $28571 \mathrm{~cm}^{-1}$ and $37037 \mathrm{~cm}^{-1}$ may be assigned to the spinforbidden electronic transitions from ground sextet term ${ }^{6} \mathrm{~A}_{1 \mathrm{~g}}$ to ${ }^{4} \mathrm{~T}_{1 \mathrm{~g}}(\mathrm{G}),{ }^{4} \mathrm{~T}_{2 \mathrm{~g}}(\mathrm{G}),{ }^{4} \mathrm{~A}_{1 \mathrm{~g}}(\mathrm{G}),{ }^{4} \mathrm{E}_{\mathrm{g}}(\mathrm{G})$ and ${ }^{4} \mathrm{E}_{\mathrm{g}}(\mathrm{D})$ respectively; other two bands at $40000 \mathrm{~cm}^{-1}$ and $47619 \mathrm{~cm}^{-1}$ correspond to charge transfer transitions $[12,13]$.

Observed magnetic moment of Co(II) complex, 3.37 BM, and absorption bands at $14925 \mathrm{~cm}^{-1}, 17544 \mathrm{~cm}^{-1}$ and 24390 $\mathrm{cm}^{-1}$ attributed to ${ }^{4} \mathrm{~T}_{1 \mathrm{~g}} \rightarrow{ }^{4} \mathrm{~T}_{2 \mathrm{~g}}(\mathrm{~F}),{ }^{4} \mathrm{~T}_{1 \mathrm{~g}} \rightarrow{ }^{4} \mathrm{~T}_{1 \mathrm{~g}}(\mathrm{P})$ and ${ }^{4} \mathrm{~T}_{1 \mathrm{~g}} \rightarrow$ ${ }^{4} \mathrm{~T}_{2 \mathrm{~g}}(\mathrm{~F})$ respectively are consistent with spin free octahedral geometry $[14,15]$ of this paramagnetic. Additional bands displayed in $30303-47619 \mathrm{~cm}^{-1}$ region of spectrum are due to charge transfer transitions.

The lower magnetic moment of Ni(II) complex, 1.25 BM, than spin-only value of spin free $\mathrm{d}^{8}$ configuration $(2.83 \mathrm{BM})$ indicates the presence of both spin paired and spin free,

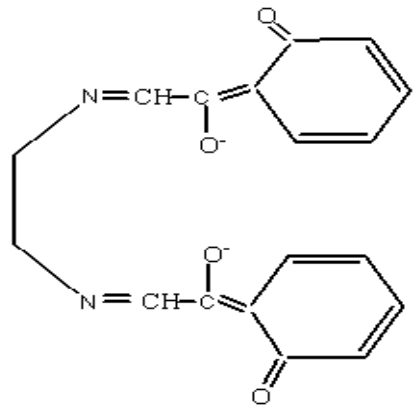

(a) states in equilibrium in the solid. However spectral bands occurring at $23529 \mathrm{~cm}^{-1}$ and $28572 \mathrm{~cm}^{-1}$ are characteristic of ${ }^{1} \mathrm{~A}_{1 \mathrm{~g}} \rightarrow{ }^{1} \mathrm{~B}_{1 \mathrm{~g}}$ and ${ }^{1} \mathrm{~A}_{1 \mathrm{~g}} \rightarrow{ }^{1} \mathrm{~A}_{2 \mathrm{~g}} \mathrm{~d}$-d transitions respectively of square planar spin paired geometry $[12,16]$ of this complex. High frequency bands spreading over 33898$45456 \mathrm{~cm}^{-1}$ region correspond to charge transfer transitions.

The magnetic moments of both $\mathrm{Cu}$ (II) complexes, 1.23 $\mathrm{BM}$ and $1.19 \mathrm{BM}$, are lower than spin-only value of $\mathrm{d}^{9}$ configuration most probably due to the presence of antiferromagnetic interactions in these trinuclear paramagnetics. Three bands occurring in $24390-25000 \mathrm{~cm}^{-1}$, $26316-27027 \mathrm{~cm}^{-1}$ and 28986-30303 $\mathrm{cm}^{-1}$ regions of electronic spectra attributed to ${ }^{2} \mathrm{~B}_{1 \mathrm{~g}} \rightarrow{ }^{2} \mathrm{~A}_{1 \mathrm{~g}},{ }^{2} \mathrm{~B}_{1 \mathrm{~g}} \rightarrow{ }^{2} \mathrm{~B}_{2 \mathrm{~g}}$ and ${ }^{2} \mathrm{~B}_{1 \mathrm{~g}} \rightarrow{ }^{2} \mathrm{E}_{\mathrm{g}}$ transitions respectively of their square planar geometry $[17,18]$. As a typical example structure of monoligand trinuclear $\mathrm{Cu}(\mathrm{II})$ complex is shown in Figure 1.

The perusal of antimicrobial activities of the compounds (Table 2) reveals that the complexes possess greater bactericidal and fungicidal activities against all the microbes in comparison to ligand which is due to their higher lipophilicity. This modified antimicrobial behavior of the complexes may be accounted for on the basis of Chelation Theory and Overtones Concept [19]. Among all the compounds $\mathrm{Zn}$ (II) complex which showed highest antimicrobial activity against both test bacteria and antifungal activity against $\mathrm{A}$. niger and greater than standard drugs, could be considered a promising drug against these microbes.

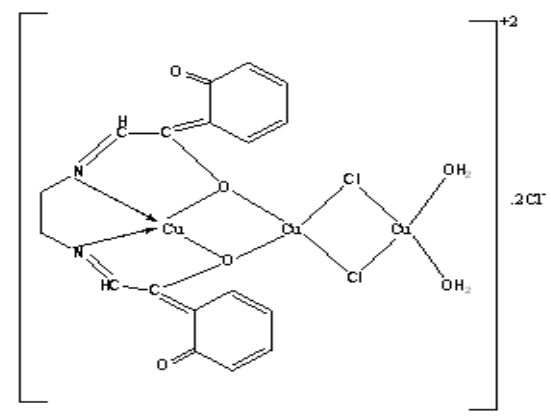

(b)

Figure 1. Structures of a) quinonoid Ligand and b) $\mathrm{Cu}(\mathrm{II})$ monoligand complex

Table 2. Antimicrobial activity data of Compounds

\begin{tabular}{|c|c|c|c|c|c|c|c|c|c|c|c|c|c|}
\hline \multirow[t]{2}{*}{ S.N } & \multirow[t]{2}{*}{ Compounds } & \multicolumn{6}{|c|}{$\begin{array}{l}\text { Inhibition Zone }(\mathrm{mm}) \\
\text { Bacteria }\end{array}$} & \multicolumn{6}{|c|}{$\begin{array}{l}\text { Fungi } \\
\text { C.gloeosporioides }\end{array}$} \\
\hline & & $10 \mu \mathrm{l}$ & $20 \mu l$ & $10 \mu l$ & $20 \mu l$ & $10 \mu \mathrm{l}$ & $20 \mu l$ & $10 \mu \mathrm{l}$ & $20 \mu l$ & $10 \mu \mathrm{l}$ & $20 \mu l$ & $10 \mu l$ & $20 \mu \mathrm{l}$ \\
\hline 1 & Ligand & 7 & 9 & - & - & - & - & 9 & 11 & - & - & 7 & 10 \\
\hline 2 & {$\left[\mathrm{Cr}_{2} \mathrm{~L}\left(\mathrm{H}_{2} \mathrm{O}\right)_{2} \mathrm{Cl} 4\right] .6 \mathrm{H}_{2} \mathrm{O}$} & 12 & 13 & $\mathrm{x}$ & $\mathrm{X}$ & 7 & 8 & 10 & 12 & $\mathrm{x}$ & $\mathrm{x}$ & 9 & 12 \\
\hline 3 & {$\left[\mathrm{FeL}\left(\mathrm{H}_{2} \mathrm{O}\right) \mathrm{Cl}\right] .6 \mathrm{H}_{2} \mathrm{O}$} & 10 & 11 & $\mathrm{x}$ & $X$ & 6 & 10 & 10 & 11 & $\mathrm{x}$ & $\mathrm{x}$ & 8 & 11 \\
\hline 4 & {$\left[\mathrm{CoL}\left(\mathrm{H}_{2} \mathrm{O}\right)_{2}\right] \cdot 4 \mathrm{H}_{2} \mathrm{O}$} & 8 & 10 & $\mathrm{x}$ & $\mathrm{X}$ & 6 & 7 & 9 & 10 & $\mathrm{x}$ & $\mathrm{x}$ & 8 & 11 \\
\hline 5 & {$[\mathrm{NiL}] . \mathrm{H}_{2} \mathrm{O}$} & 15 & 18 & 13 & 22 & $\mathrm{x}$ & $\mathrm{x}$ & $\mathrm{x}$ & $\mathrm{x}$ & 15 & 20 & 15 & 22 \\
\hline 6 & {$\left[\mathrm{Cu}_{3} \mathrm{~L}_{2}\right]^{+2} \cdot 2 \mathrm{Cl}^{-} \cdot 4 \mathrm{H}_{2} \mathrm{O}$} & 17 & 19 & 25 & 31 & $\mathrm{x}$ & $\mathrm{x}$ & $\mathrm{x}$ & $\mathrm{x}$ & 13 & 20 & 8 & 25 \\
\hline 7 & {$\left[\mathrm{Cu}_{3} \mathrm{LCl}_{2}\left(\mathrm{H}_{2} \mathrm{O}\right)_{2}\right] \cdot 2 \mathrm{Cl}^{-}$} & 17 & 20 & 22 & 27 & $\mathrm{x}$ & $\mathrm{x}$ & $\mathrm{x}$ & $\mathrm{x}$ & 8 & 12 & 10 & 15 \\
\hline 8 & {$\left[\mathrm{Zn}_{2} \mathrm{LCl}\left(\mathrm{H}_{2} \mathrm{O}\right)\right]^{+} \cdot \mathrm{Cl}^{-} .4 \mathrm{H}_{2} \mathrm{O}$} & 23 & 25 & 25 & 32 & $\mathrm{x}$ & $\mathrm{x}$ & $\mathrm{x}$ & $\mathrm{x}$ & 12 & 18 & 19 & 27 \\
\hline 9 & DMSO (Control) & - & - & - & - & - & - & - & - & - & - & - & - \\
\hline 10 & Chlroamphinicol & 21 & 23 & 25 & 30 & 27 & 31 & - & - & - & - & - & - \\
\hline 11 & Bavistin & - & - & - & - & - & - & 30 & 35 & 15 & 20 & 20 & 25 \\
\hline
\end{tabular}

$\mathrm{x}=$ not attempted 


\section{References}

[1] Z. H.Chohan, A. Munawar and C. T. Supuran, 2001. Transition metal ion complexes of Schiff's-bases synthesis, characterization and antibacterial properties. Metal-based drugs, 8: 137-143.

[2] E. Canpolat, and M. Kaya, 2004. Studies on mononuclear chelates derived from substituted Schiff-base ligands (part 2): synthesis and characterization of a new 5bromosalicyliden paminoacetophenone oxime and its complexes with $\mathrm{Co}(\mathrm{II}), \mathrm{Ni}(\mathrm{II}), \mathrm{Cu}(\mathrm{II})$ and $\mathrm{Zn}(\mathrm{II}) \mathrm{J}$. Coord. Chem. 123.

[3] Abdel-Rahman, L.H., El-Khatib, R.M., Nassr, L.A.E., and Abu-Dief, A. M., J. Mole. Struct., 2013, vol. 1040, p. 9.

[4] R.K. Upadhyay, N.Agarwal, Nat. Acad. Sci.Letters, 14, 251 (1991).

[5] R.K. Upadhyay, J. Indian Chem. Soc., 75,535 (1997).

[6] M. B.Ferrari, , S. Capacchi, G. Pelosi, G. Reffo, P. Tarasconi, R .Albertini, S. Pinelli, P. Lunghi, 1999. Synthesis, structural characterization and biological activity of helicin thiosemicarbazone monohydrate and a Copper(II) complex of salicylaldehyde thiosemicarbazone Inorg. Chim. Acta, 286, 134-141.

[7] R.K. Upadhyay, V. Sharma, V.P. Singh, J. Liq. Chromatogr., $5,1141(1982)$.
[8] R.K. Upadhyay, A.K. Bajpai, K.Rathore, Chromatographia, 18,618 (1984).

[9] D.L. Drew, A.L. Barry, R.O. Toole, J.C. Sherris, Appl. Environ. Microbial, 24,240 (1972).

[10] W.J. Greay, Coordination Chemistry Reviews, Vol. 7, No.1, 81-122 (1971).

[11] R.K. Upadhyay, A. Rani, Acta Chim. Hung., 126,195 (1989).

[12] K.Nakamoto, Infrared Spectra of Inorganic and Coordination Compounds, Wiley-Interscience, N.Y., P. 295, 1970.

[13] A.B.P. Lever, Inorganic Electronic Spectroscopy, Elsevier, Amsterdam, the Netherlands, 1978.

[14] G.H. Anuradha, A.V. Chandrapal; E-J. Chem., 8,421 (2011).

[15] P.S. Badami, A.D. Kulkarni, S.A. Patil, J. Electrochem. Sci., 4, 717 (2019).

[16] A.A. Elamari, A.N. El-Tajoury, S.A. I. Sharif, E-J. Chem., 8, 43 (2011).

[17] A.A. Del Paggio, D.R. McMillin, Inorg. Chem. 22.691 (1983).

[18] R.K. Upadhyay, Ph.D. Thesis, Meerut Univ, Meerut, 1972.

[19] S. Chandra, D. Jain, A.K. Sharma, P. Sharma, Molecules, 14,174 (2009). 